TÜRKIYE'DE ÜNIVERSITELER VOLEYBOL 2. LIGINDE OYNAYAN ÖĞRENCİ-SPORCULARIN İLETISSIM VE PERFORMANS VERIMINE YÖNELIKK GÖRÜŞLERININ INCELENMESI' ${ }^{1}$

\title{
ANALYSIS OF THE OPINIONS OF STUDENT-ATHELETES PLAYING IN THE UNIVERSITIES VOLLEYBALL 2ND LEAGUE IN TURKEY TOWARDS COMMUNICATION AND PERFORMANCE EFFICIENCY
}

\author{
Serkan HACICAFEROĞLU ${ }^{1}$, Murat KORKMAZ2, Ahmet ATALAY', \\ Ali Serdar YÜCEL ${ }^{4}$ \\ ${ }^{1}$ Recep Tayyip Erdoğan Üniversitesi BESYO Rize / Türkiye \\ ${ }^{2}$ Finans yönetmeni, Güven Grup A.Ş. İstanbul / Türkiye \\ ${ }^{3}$ Ardahan Üniversitesi, BESYO, Ardahan / Türkiye \\ ${ }^{4}$ Ftrat Üniversitesi, Spor Bilimleri Fakültesi Elazı̆ / Türkiye
}

Öz: Bu araştırmanın amacı 16-27 Aralık 2014 tarihlerinde Antalya'da düzenlenen Üniversiteler Voleybol İkinci Lig müsabakalarına katılan öğrenci-sporcuların iletişimin performans verimine etkisine ilişkin görüşlerinin farklı değişkenler açısından incelenmesidir. Araştırmanın çalışma evrenini Türkiye'de üniversitelerde eğitim gören ve aynı zamanda üniversitelerin voleybol takımlarında yer alan öğrenci sporcular oluş̧urmakla birlikte örneklem grubunu 16-27 Aralık 2014 tarihlerinde Antalya'da düzenlenen Üniversiteler Voleybol İkinci Lig müsabakalarına katılan 23 farklı üniversitenin öğrenci-sporcuları oluşturmaktadır. Öğrenci-sporcuların iletişimin performans verimine etkisine yönelik görüşlerini belirlemek amacı ile katılımcılara anket uygulanmıştır. Uygulanan anketin Cronbach's Alpha kat sayısı olarak 0.925 değeri elde edilmiştir. Man Whitney U, Kruskal Wallis, Jonckheere-Terpstra ve Ki-Kare teknikleri uygulanarak araştırma genişletilmiştir. Sonuç olarak üniversitelerin voleybol takımlarında yer alan öğrencilerin iletişimin performans verimine etkisine iliş̧kin görüşlerinin cinsiyet, üniversite ve not ortalaması değişkenleri açısından anlamlı farklılıklar ortaya koyduğu tespit edilmiştir.

Anahtar Kelimeler: Voleybol, Performans Verimi, İletişim
Abstract: This study aims to analyze the opinions of student-volleyball players, who join the Interuniversity Volleyball Minor League that was held in Antalya between 16-27 December 2014, regarding the impact of communication on performance capacity by different variables. Target population of the study consists of student-volleyball players who study at a university in Turkey and play for volleyball teams of universities in the meantime whereas the sample group consists of student-volleyball players from 23 different universities who join the Interuniversity Volleyball Minor League that was held in Antalya between 16-27 December 2014. A survey has been conducted on the participants to analyze the opinions of student-volleyball players regarding the impact of communication on performance capacity. The survey has been extended applying Man Whitney U, Kruskal Wallis, Jonckheere-Terpstra and Chi-Square techniques. As a result, meaningful differences have been detected between the opinions of students, who play in university volleyball teams, regarding the impact of communication on performance capacity by gender, university, grade point average variables.

Key Words: Volleyball, Performance Efficiency, Communication

Doi: 10.17363/SSTB.20151610878

(1) Sorumlu Yazar: Ali Serdar YÜCEL, Furat Üniversitesi Spor Bilimler Fakültesi / Türkiye alsetu_23@hotmail. com Geliş Tarihi / Received: 04.12.2014 Düzeltme Tarihi / Revision Date 04.02.2014 Kabul Tarihi/Accepted: 29.04.2015 Makalenin Türü: Type ofarticle (Araştırma - Uygulama / Research -Application) Çıkar Çatışması / Conflict of Interest:Yok / None“Etik Kurul Raporu Yok - Noneof Ethics Committee” (Araştırmada Kurum İni Var / Yok) "YOK" "The Research Council Permit Yes / No" "NO" 


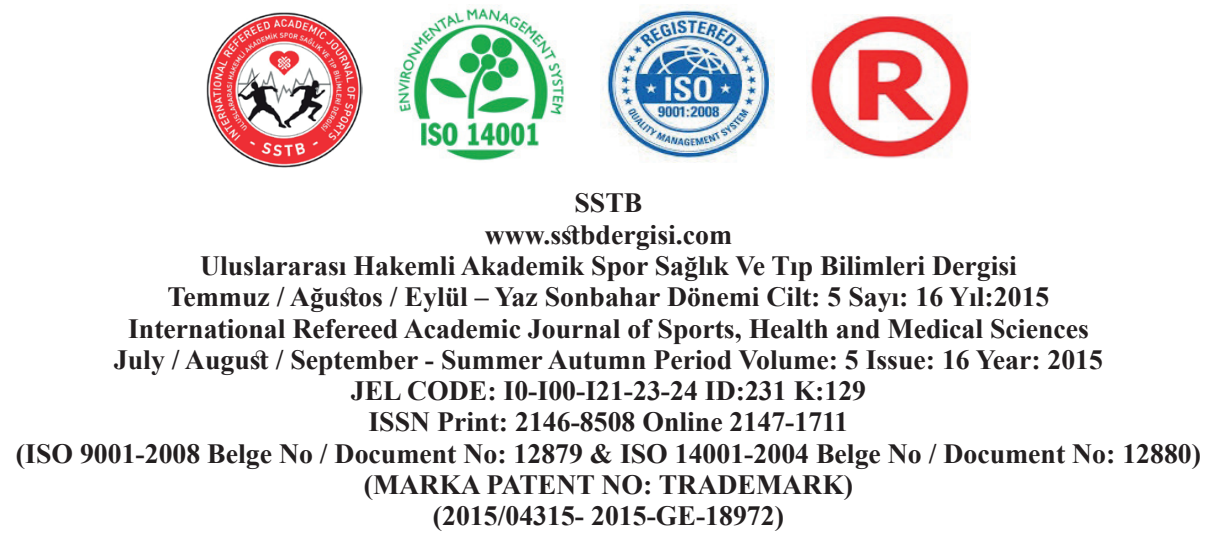

\section{GíRiş}

Toplumsal yapının korunması ve uyumun sağlanması ve geliştirilmesi bireyler arasında sağlıklı bir iletişimin yapılandırılması ile mümkündür. Dolayısı ile hem bireyler hem de toplum için iletişim son derece önemlidir.

İletişim, bilgi yaratıp karşı1lıklı bir anlamaya ulaşmak amaciyla bu bilgiyi kişilerin birbirleri ile paylaştıkları bir süreçtir (Çamdereli, 2008). Girgin (2002), iletişimi en yalın biçimi ile bir kaynağın alıcıya (hedefe kitleye) belirli bir kanaldan ileti gönderimi olarak tanımlarken, Özkan (2010) ise iletişimi duygu düşünce ve bilgileri çeşitli yollarla başkalarına aktarma ve anlamlandırma süreci olarak değerlendirmektedir.

İnsanların birbirleri ile iletişim kurma ihtiyacı temel olarak sosyal yaşamın bir gereğidir. İletişim, ilişki kurma ihtiyacından ve karşılıklı bir takım hedeflere ulaşma çabasından doğar (Hergüner vd., 1997). Oskay (2011), iletişimin insanın varlık sürdürme biçiminin bir ürünü ve insanın varlık sürdürme biçimindeki gelişmelere göre değişimlere uğrayan insana özgü bir olgu olduğunu ortaya koymaktadır. Güngör (2011) ise, toplumsal bir bütün olmak, bir şeylerin paylaşıldığı insan topluluğu olabilmek, dahası örgütsel bir toplum yapısı oluşturabilmek için iletişimin temel bir öncül olduğuna dikkat çekmektedir.

Sermaye, üretim ve tüketim süreçlerinin tamamında insanın yer aldığı spor ortamında iletişim, gerek performans gerekse de nitelikli zaman geçirme adına oldukça önemlidir. Zira merkezinde insan unsuru yer almaktadır. Dolayısı ile sosyal bir varlık olan insanın iletişim kurma ihtiyacı ve gerekliliği spor alanlarında da önemlidir. İletişim özellikle performansa yönelik spor etkinliklerinde gerek bireysel gerekse de takım başarısında önemli bir role sahiptir. Özellikle takım sporlarında sağliklı bir iletişimin kurulmasının yüksek performansın sergilenmesi ve başarının elde edilmesinde belirleyici bir unsur olduğu söylenebilir.

Takım başarısının değerlendirilmesi, antrenör ve sporcu arasındaki iyi iletişimin ve antrenörden sporcuya doğru oluşan ödüllendirme davranışı akıșı ile belirlenir. Ayrıca iyi iletișim kurmak sporcular arasında olumlu eleştiri ve sürekli etkileşim sağlar (Ulukan, 2012).

Y1ldırım ve Abakay (2015), spor ortamında bireylerin birbirleri ile sürekli iletişim içinde olduklarını, müsabaka ve antrenmanlarda çeşitli duygu ve düşünceleri paylaştıklarını ifade ederken aynı zamanda takım sporcularında iletişim becerilerinin yükssek olmasının gerekliliğine dikkat çekmektedir.

Takım sporlarında grup içi iletişimin yükssek olması durumunda takım performansının olumlu yönde etkilenebileceği söylenebilir. Düşünce ve davranış biçimlerinin geliştirilmesi ve pozitif yönde değiştirilmesi etkili bir iletişim ağının sağlanması ile mümkün gözükmektedir.

İletişim antrenör ve sporcular arasında davranış değişikliği meydana getirmek üzere fikir, bilgi, 


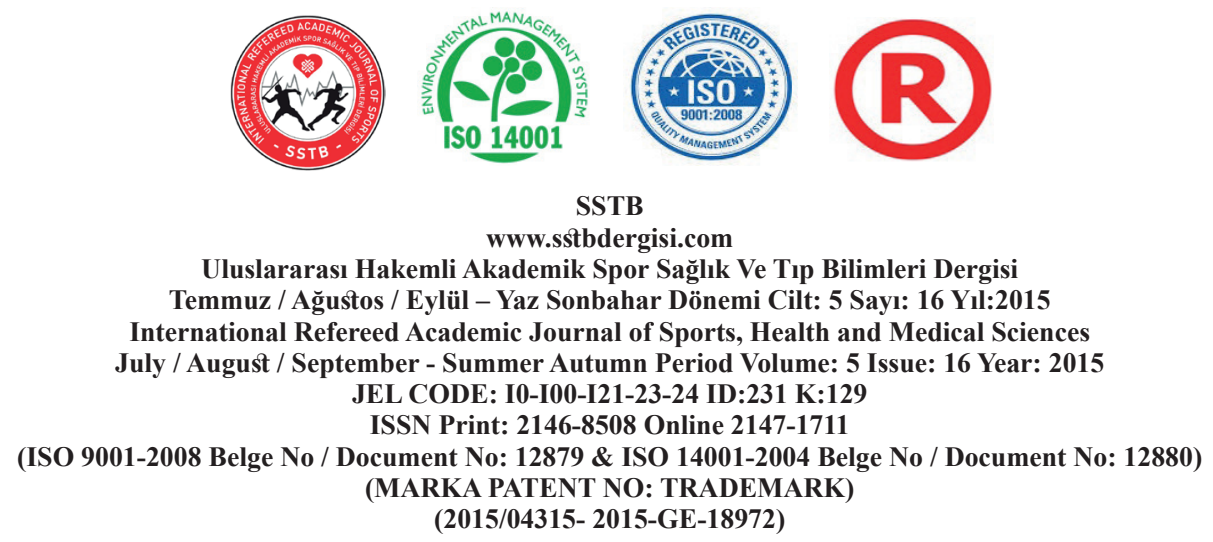

tutum, duygu ve becerilerin paylaşılması sürecinde önemli bir unsurdur (Yetim ve Cengiz, 2010).

Hem takım sporlarında hem de bireysel sporlarda temel amaç en üst düzey performans ortaya koymak ve başarı elde etmektir. Dolayısı ile takım sporlarında grup üyeleri arasındaki iletişimin sağlıklı olması ve akabinde başarılı bir performansın sergilenmesi elzemdir. Bu süreçte iletişim ağının güçlendirilmesi ile birlikte bireyler arasında ve takım içindeki uyum artacak ve başarı elde edilecektir. $\mathrm{Bu}$ açıdan değerlendirildiğinde takım sporlarında iletişimin önemi bir hayli büyüktür. Yetersiz iletişim, empati ve öz eleştiri yeteneğini güçleştireceğinden takımın başarılı olması diğer faktörlerin daha güçlü olmasına bağlı olacaktır. Dolayısı ile bu riskin ortadan kaldırılması adına takım sporlarında iletişimin bilimsel veriler desteklenerek güçlendirilmesi, antrenör ve yöneticilerin bu sürece profesyonel bir şekilde yaklaşması gerekmektedir. Günümüzde performansa ve başarıya yüklenen anlam bir hayli büyüktür. Özellikle takım sporlarında tek tek başarılı sporculardan bir araya gelmiş olan bir grubun başarılı bir takım olabilmesinde iletişim son derece etkilidir. Multidisipliner yapısı itibari ile spor bilimleri ve iletişim arasındaki ilişki sporcu özelinde ortaya konularak takım sporlarında daha iyiye ulaşma sürecinde kullanılabilecek en önemli araçların başında iletişim gelmektedir.

$\mathrm{Bu}$ durum kapsamlı bir süreci ifade ederken bu süreçte kullanılabilecek bir çok argümandan birisi de sporcu ve antrenör arasında nitelikli bir iletişim kanalının oluşturulmasıdır. Antrenör ve sporcu arasında performansın artırılması amacı ile etkili bir bilgi akışının sağlanması iletişim becerilerinin geliştirilmesi ile mümkün olacaktır. Dolayısı ile sağlıklı bir iletişimin oluşturulması bireysel ve takım performansını yukarılara çekecektir.

$\mathrm{Bu}$ araştırmanın amacı üniversitelerin futsal takımlarında yer alan öğrenci sporcuların iletişim ve takım performanslarının çeşitli değişkenler açısından incelenmesidir.

\section{MATERYAL METOD}

Öğrenci-sporcuların iletişimin performans verimine etkisine yönelik görüşlerinin farklı değişkenler açısından incelenmesi amacıyla gerçekleştirilen çalsşmada verilerin elde edilmesinde anket kullanılmıştır. Kullanılan anket Yıldız (2004) tarafindan geliştirilen ve Cronbach's Alpha güvenirlik katsayısı .86 olarak tespit edilmiş forumdur. Araştırmada elde edilen veriler SPSS (Statistical Package for Social Sciences) for Windows 21.0 programı kullanılarak analiz edilmiştir. Verilerin analizinde Mann Whitney U, Kruskal Wallis, Jonckheere-Terpstra ve Ki-Kare testleri kullanılmıştır. Elde edilen bulgular \%95 güven aralığında, \%5 anlamlılık düzeyinde değerlendirilmiştir. Ölçeğin güvenilirliğini test etmek amaciyla Cronbach's alpha analizi uygulanmış ve Cronbach's alpha değeri 0,925 olarak bulunmuştur. 

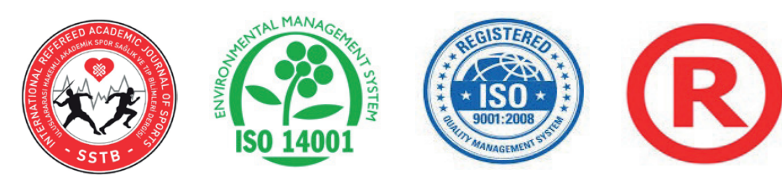

SSTB

www.sstbdergisi.com

Uluslararası Hakemli Akademik Spor Sağlık Ve Tıp Bilimleri Dergisi

Temmuz / Ağustos / Eylül - Yaz Sonbahar Dönemi Cilt: 5 Sayı: 16 Yıl:2015

International Refereed Academic Journal of Sports, Health and Medical Sciences

July / August / September - Summer Autumn Period Volume: 5 Issue: 16 Year: 2015 JEL CODE: I0-I00-I21-23-24 ID:231 K:129

ISSN Print: 2146-8508 Online 2147-1711

(ISO 9001-2008 Belge No / Document No: 12879 \& ISO 14001-2004 Belge No / Document No: 12880) (MARKA PATENT NO: TRADEMARK)

(2015/04315- 2015-GE-18972)

\section{BULGULAR}

Tablo 1. Katılımcılara ilişkin bazı demografik dağılımlar

\begin{tabular}{|c|c|c|c|c|}
\hline & & Ortalama & Frekans & Sütun N \% \\
\hline \multicolumn{5}{|c|}{21.28} \\
\hline \multirow[t]{3}{*}{ Yaş Gup } & $18-20$ & & 132 & $33,42 \%$ \\
\hline & $21-23$ & & 218 & $55,19 \%$ \\
\hline & $24-25$ & & 45 & $11,39 \%$ \\
\hline \multirow[t]{2}{*}{ Cinsiyet } & Bay & & 203 & $51,39 \%$ \\
\hline & Bayan & & 192 & $48,61 \%$ \\
\hline \multirow[t]{23}{*}{ Okul } & 1,00 & & 24 & $6,08 \%$ \\
\hline & 2,00 & & 24 & $6,08 \%$ \\
\hline & 3,00 & & 24 & $6,08 \%$ \\
\hline & 4,00 & & 12 & $3,04 \%$ \\
\hline & 5,00 & & 24 & $6,08 \%$ \\
\hline & 6,00 & & 24 & $6,08 \%$ \\
\hline & 7,00 & & 24 & $6,08 \%$ \\
\hline & 8,00 & & 12 & $3,04 \%$ \\
\hline & 9,00 & & 12 & $3,04 \%$ \\
\hline & 10,00 & & 12 & $3,04 \%$ \\
\hline & 11,00 & & 24 & $6,08 \%$ \\
\hline & 12,00 & & 24 & $6,08 \%$ \\
\hline & 13,00 & & 24 & $6,08 \%$ \\
\hline & 14,00 & & 24 & $6,08 \%$ \\
\hline & 15,00 & & 12 & $3,04 \%$ \\
\hline & 16,00 & & 12 & $3,04 \%$ \\
\hline & 17,00 & & 12 & $3,04 \%$ \\
\hline & 18,00 & & 12 & $3,04 \%$ \\
\hline & 19,00 & & 11 & $2,78 \%$ \\
\hline & 20,00 & & 12 & $3,04 \%$ \\
\hline & 21,00 & & 12 & $3,04 \%$ \\
\hline & 22,00 & & 12 & $3,04 \%$ \\
\hline & 23,00 & & 12 & $3,04 \%$ \\
\hline \multirow[t]{5}{*}{ Not ortalaması } & $1-1.99$ & & 28 & $7,09 \%$ \\
\hline & $2-2.49$ & & 151 & $38,23 \%$ \\
\hline & $2.5-2.99$ & & 142 & $35,95 \%$ \\
\hline & $3-3.49$ & & 56 & $14,18 \%$ \\
\hline & $3.5-4$ & & 18 & $4,56 \%$ \\
\hline \multirow[t]{6}{*}{ Aile gelir } & $0-499$ & & 22 & $5,57 \%$ \\
\hline & $500-999$ & & 75 & $18,99 \%$ \\
\hline & $1000-1499$ & & 110 & $27,85 \%$ \\
\hline & $1500-1999$ & & 68 & $17,22 \%$ \\
\hline & $2000-2499$ & & 48 & $12,15 \%$ \\
\hline & $2500+$ & & 72 & $18,23 \%$ \\
\hline \multirow[t]{6}{*}{ Aile eğitim } & İlköğretim & & 69 & $17,47 \%$ \\
\hline & Orta öğretim & & 189 & $47,85 \%$ \\
\hline & Yüksekokul & & 81 & $20,51 \%$ \\
\hline & Lisans & & 35 & $8,86 \%$ \\
\hline & Yüksek lisans & & 16 & $4,05 \%$ \\
\hline & Doktora & & 5 & $1,27 \%$ \\
\hline
\end{tabular}




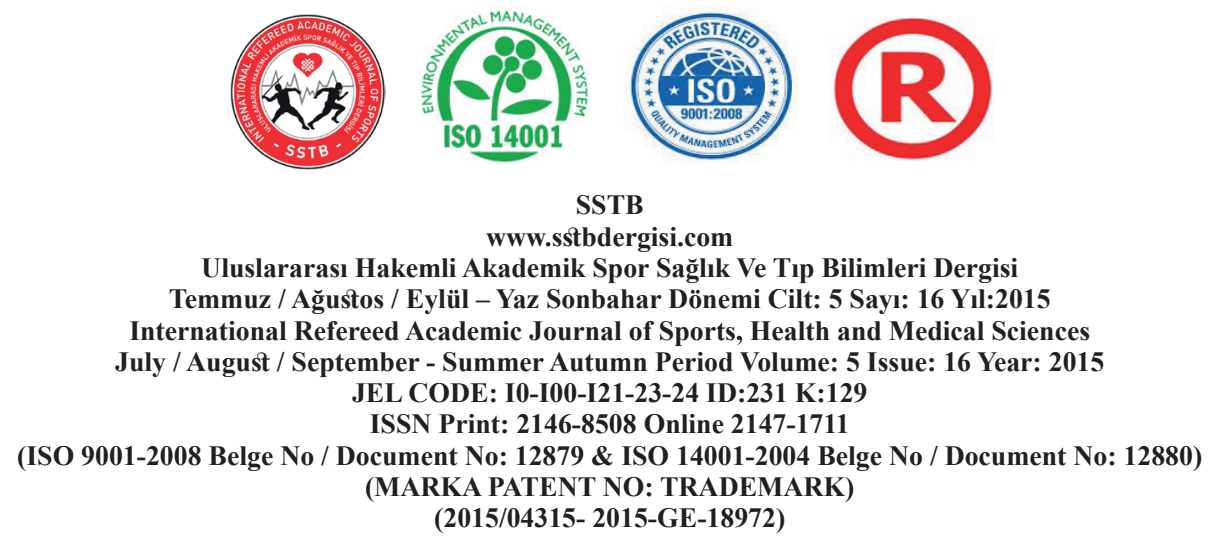

Tablo 1'e göre sporcuların çoğunluğunun yaş ortalamas1 21,28'dir, \%51,4'ü erkek, \%48,6's1 kız öğrencidir. Sporcuların not ortalamasına bakıldığında çoğunluğun $(\% 38,2)$ 2-2.49 ile $(\% 35,9)$ 2.5-2.99 arasında yer aldığı görülmektedir. Sporcuların gelir durumu değerlerine bakıldığında 97'si (\%24,6) 1000 TL alt1, 110'u (\%27,8) 1000-1499 TL aras1, 68'i $(\% 17,2)$ 1500-1999 TL aras1, 48'i $(\% 12,2)$
2000-2499 TL aras1, 72'si (\%18,2) 2500 TL ve üzeri olarak dağılım göstermektedir.

Sporcuların aile eğitim durumları ise $69^{\prime} \mathrm{u}(\% 17,5)$ İlk Öğretim, 189’u (\%47,8) Orta Öğretim, 81’i $(\% 20,5)$ Yüksekokul, 35’i $(\% 8,9)$ Lisans, 16's1 $(\% 4,05)$ lisansüstü, 5'i $(\% 1,27)$ doktora olarak dağılmaktadır.

Tablo 2. Cinsiyet Değişkenine Göre Man Whıtney U W Wilcoxon Analizi Değerleri

\begin{tabular}{|c|c|c|c|c|}
\hline & Mann-Whitney U & Wilcoxon W & $\mathrm{Z}$ & $\mathrm{P}$ \\
\hline $\begin{array}{l}\text { Antrenörün yeterli bilgi birikimine ve deneyimine } \\
\text { sahip olması performansı etkiler }\end{array}$ & 19454,000 & 37982,000 &,- 032 & ,974 \\
\hline $\begin{array}{l}\text { Antrenman ve müsabaka dönemleri dışında antre- } \\
\text { nörle sosyal ve kültürel ilişki kurulmalıdır }\end{array}$ & 17561,500 & 36089,500 & $-1,824$ & ,068 \\
\hline $\begin{array}{l}\text { Antrenör takımda arkadaşlık ilişkilerine çok özen } \\
\text { gösterir }\end{array}$ & 17978,000 & 36506,000 & $-1,437$ &, 151 \\
\hline $\begin{array}{l}\text { Antrenörün takımdaki sporcuları takdir etmesi } \\
\text { performansı etkiler }\end{array}$ & 18341,000 & 36677,000 &,- 996 & ,319 \\
\hline $\begin{array}{l}\text { Antrenörün sporcuların özel yaşantıları ile ilgilen- } \\
\text { mesi takımın performansını etkiler }\end{array}$ & 18307,000 & 39013,000 & $-1,107$ & ,268 \\
\hline $\begin{array}{l}\text { Antrenörün sert ve kırıcı konuşması performansı } \\
\text { etkilemez }\end{array}$ & 18577,000 & 39283,000 &,- 862 & ,388 \\
\hline $\begin{array}{l}\text { Takım içinde sporcular üzerine düşen sorumluluk- } \\
\text { ları yerine getirirler }\end{array}$ & 18087,500 & 36615,500 & $-1,307$ & ,191 \\
\hline $\begin{array}{l}\text { Yedek olunan maçlarda bile takımın başarısı önem- } \\
\text { senir }\end{array}$ & 18851,500 & 39557,500 &,- 601 &, 548 \\
\hline $\begin{array}{l}\text { Takım arkadaşları ile sorunları konuşabilmek } \\
\text { performansı etkiler }\end{array}$ & 19394,000 & 37922,000 &,- 087 & ,930 \\
\hline $\begin{array}{l}\text { Takım başarısında oynayanlar kadar yedek oyun- } \\
\text { cularında etkisi vardır }\end{array}$ & 17863,500 & 36391,500 & $-1,523$ & ,128 \\
\hline $\begin{array}{l}\text { Takımla ilgili önemli kararlar alınmadan önce } \\
\text { tüm oyuncuların fikirlerinin alınması performansı } \\
\text { etkiler }\end{array}$ & 19294,000 & 37822,000 &,- 182 & ,855 \\
\hline
\end{tabular}



JEL CODE: I0-I00-I21-23-24 ID:231 K:129

ISSN Print: 2146-8508 Online 2147-1711

(ISO 9001-2008 Belge No / Document No: 12879 \& ISO 14001-2004 Belge No / Document No: 12880) (MARKA PATENT NO: TRADEMARK) (2015/04315- 2015-GE-18972)

\begin{tabular}{|l|l|l|l|l|}
\hline $\begin{array}{l}\text { Önemli maçlar öncesinde takım içindeki dayanış- } \\
\text { ma ve yardımlaşma performansı etkiler }\end{array}$ & 18867,500 & 37395,500 &,- 597 &, 550 \\
\hline $\begin{array}{l}\text { Aynı mevkii paylaşan sporcuların rekabeti perfor- } \\
\text { mansı etkiler }\end{array}$ & 18080,000 & 36608,000 & $-1,367$ &, 172 \\
\hline $\begin{array}{l}\text { Başarısız olunan maçlardan sonra başarısızlığın } \\
\text { nedenlerinin tartışıması performansı etkiler }\end{array}$ & 17157,000 & 35685,000 & $-2,228$ &, 026 \\
\hline Takım içinde bazı oyuncular ayrıcalıklıdır & 18778,500 & 37306,500 &,- 663 &, 508 \\
\hline $\begin{array}{l}\text { Kulüpte takımın performansını olumlu yönde etki- } \\
\text { leyecek bütün olanaklar sağlanır }\end{array}$ & 18858,000 & 37386,000 &,- 595 &, 552 \\
\hline $\begin{array}{l}\text { Yöneticiler takım içindeki arkadaşlı̆ın sağlanma- } \\
\text { sında etkilidir }\end{array}$ & 19397,500 & 40103,500 &,- 085 &, 933 \\
\hline $\begin{array}{l}\text { Yöneticiler başarısız sonuçlarda bile sporcuların } \\
\text { kişilik haklarına her zaman saygı gösterir }\end{array}$ & 18914,000 & 39620,000 &,- 532 &, 594 \\
\hline $\begin{array}{l}\text { Yöneticilerin sporcular sakatlandığında maddi } \\
\text { ve manevi her türlü desteği vermesi performansı } \\
\text { etkiler }\end{array}$ & 18590,000 & 39296,000 &,- 828 &, 408 \\
\hline $\begin{array}{l}\text { Yöneticilere ulaşmada ve sorunların anlatılmasında } \\
\text { genelde sıkıntı çekilir }\end{array}$ & 17426,500 & 35954,500 & $-1,933$ &, 053 \\
\hline
\end{tabular}

H0: Cinsiyet, tercih nedenleri üzerinde farkllĭğa neden olan bir değişken değildir.

Man Whitney $U$ analizi ile cinsiyetin, tercih nedenleri üzerindeki etkisi belirlenmeye çal1şılmıştır. Buna göre; Asymp sig değeri 0,05'in üstünde bulunan tercih nedeni cinsiyete göre farklılaşmadığı, altında bulunan tercih nedeni ise cinsiyete göre farklılaştığını göstermektedir. Erkeklerin kızlara göre ortalamalarının daha yüksek olduğu bulunmuştur. Analiz sonuçlarına bakıldığında, cinsiyetin farklılığa neden olduğu yalnız bir faktör bulunmaktadır. Başarısız olunan maçlardan sonra başarısızlığın nedenlerinin tartışılması performansı etkiler $(\mathbf{9 0 2 6})$ cinsiyete göre farklılaşmaktadır. 
SSTB

Www.sstbdergisi.com

Uluslararası Hakemli Akademik Spor Sağlık Ve Tıp Bilimleri Dergisi

Temmuz / Ă̆ustos / Eylül - Yaz Sonbahar Dönemi Cilt: 5 Sayı: 16 Yıl:2015

International Refereed Academic Journal of Sports, Health and Medical Sciences

July / August / September - Summer Autumn Period Volume: 5 Issue: 16 Year: 2015

JEL CODE: I0-I00-I21-23-24 ID:231 K:129

ISSN Print: 2146-8508 Online 2147-1711

(ISO 9001-2008 Belge No / Document No: 12879 \& ISO 14001-2004 Belge No / Document No: 12880)

(MARKA PATENT NO: TRADEMARK)

(2015/04315- 2015-GE-18972)

Tablo 3. Okul değişkenine göre Kruskal Wallis Analizi değerleri

\begin{tabular}{|c|c|c|c|}
\hline & Chi-square & df & $\mathrm{p}$ \\
\hline $\begin{array}{l}\text { Antrenörün yeterli bilgi birikimine ve deneyimine sahip olması performans1 } \\
\text { etkiler }\end{array}$ & 80,499 & 22 & 000 \\
\hline $\begin{array}{l}\text { Antrenman ve müsabaka dönemleri dışında antrenörle sosyal ve kültürel ilişki } \\
\text { kurulmalıdır }\end{array}$ & 89,880 & 22 & ,000 \\
\hline Antrenör takımda arkadaşlık ilişkilerine çok özen gösterir & 54,145 & 22 &, 000 \\
\hline Antrenörün takımdaki sporcuları takdir etmesi performansı etkiler & 35,199 & 22 & ,037 \\
\hline $\begin{array}{l}\text { Antrenörün sporcuların özel yaşantıları ile ilgilenmesi takımın performansını } \\
\text { etkiler }\end{array}$ & 52,925 & 22 & ,000 \\
\hline Antrenörün sert ve kırıcı konuşması performansı etkilemez & 37,146 & 22 & ,023 \\
\hline Takım içinde sporcular üzerine düşen sorumlulukları yerine getirirler & 52,729 & 22 & ,000 \\
\hline Yedek olunan maçlarda bile takımın başarısı önemsenir & 35,850 & 22 & ,032 \\
\hline Takım arkadaşları ile sorunları konuşabilmek performansı etkiler & 32,189 & 22 & 074 \\
\hline Takım başarısında oynayanlar kadar yedek oyuncularında etkisi vardır & 18,000 & 22 & ,706 \\
\hline $\begin{array}{l}\text { Takımla ilgili önemli kararlar alınmadan önce tüm oyuncuların fikirlerinin } \\
\text { alınması performansı etkiler }\end{array}$ & 33,175 & 22 & 059 \\
\hline $\begin{array}{l}\text { Önemli maçlar öncesinde takım içindeki dayanışma ve yardımlaşma perfor- } \\
\text { mansı etkiler }\end{array}$ & 43,964 & 22 & ,004 \\
\hline Aynı mevkii paylaşan sporcuların rekabeti performansı etkiler & 40,917 & 22 & ,008 \\
\hline $\begin{array}{l}\text { Başarısız olunan maçlardan sonra başarısızlığın nedenlerinin tartışılması } \\
\text { performansı etkiler }\end{array}$ & 30,793 & 22 &, 100 \\
\hline $\begin{array}{l}\text { Kulüpte takımın performansını olumlu yönde etkileyecek bütün olanaklar } \\
\text { sağlanır }\end{array}$ & 29,504 & 22 & ,131 \\
\hline Yöneticiler takım içindeki arkadaşlığın sağlanmasında etkilidir & 36,587 & 22 & ,026 \\
\hline $\begin{array}{l}\text { Yöneticiler başarısız sonuçlarda bile sporcuların kişilik haklarına her zaman } \\
\text { saygı gösterir }\end{array}$ & 27,048 & 22 & ,209 \\
\hline $\begin{array}{l}\text { Yöneticilerin sporcular sakatlandığında maddi ve manevi her türlü desteği } \\
\text { vermesi performansı etkiler }\end{array}$ & 24,678 & 22 & ,313 \\
\hline Yöneticilere ulaşmada ve sorunların anlatılmasında genelde sıkıntı çekilir & 37,618 & 22 &, 020 \\
\hline
\end{tabular}

H0: Okul, tercih nedenleri üzerinde farklllı̆̆a neden olan bir değişken değildir.
Kruskal Wallis analizi ile üniversitenin, tercih nedenleri üzerindeki etkisi belirlenmeye çalı̧ılmışıır. 


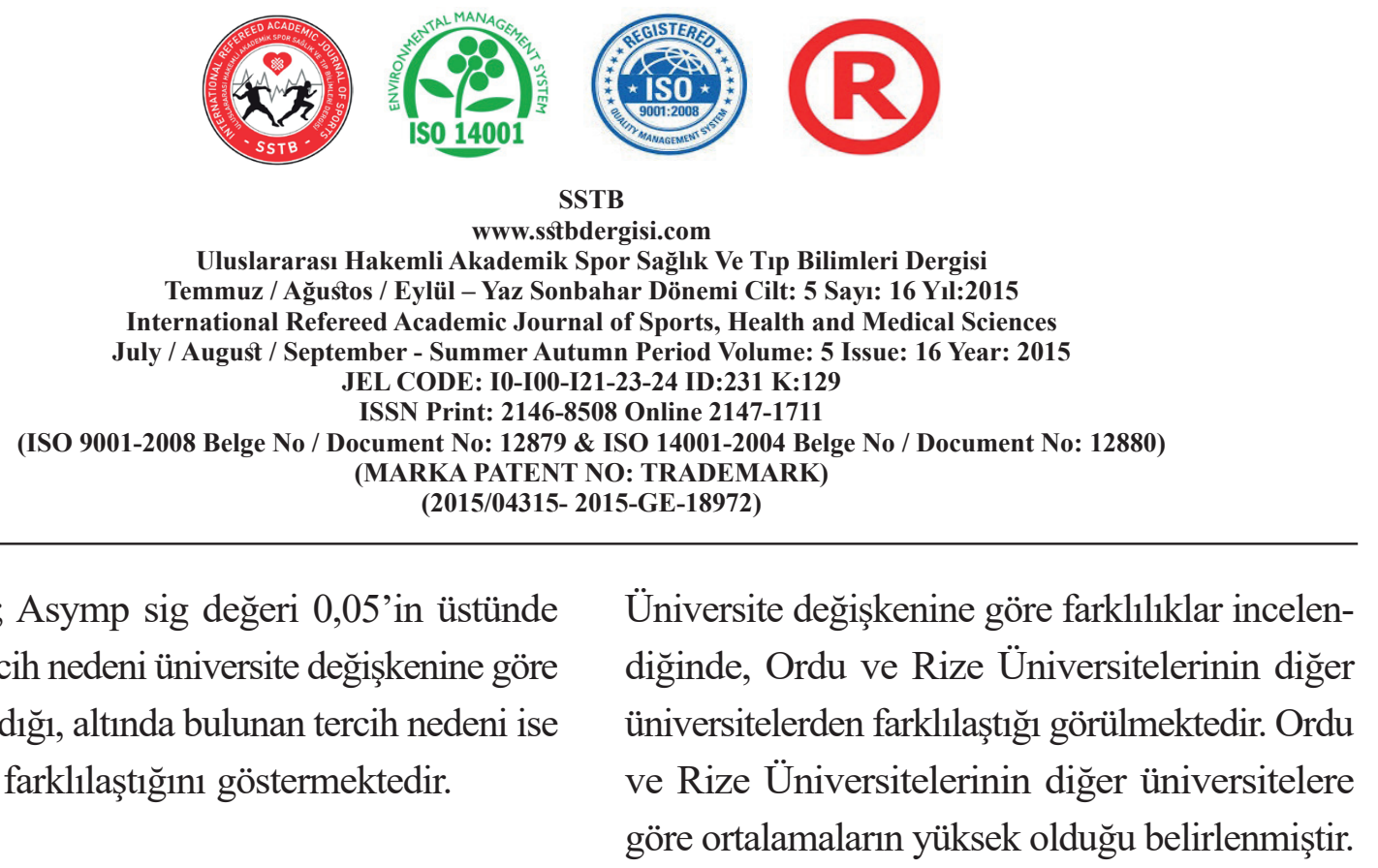

Buna göre; Asymp sig değeri 0,05'in üstünde bulunan tercih nedeni üniversite değişkenine göre farklılaşmadığı, altında bulunan tercih nedeni ise okula göre farklılaştığını göstermektedir.
Universite değişkenine göre farkliliklar incelenüniversitelerden farkliaşığ göulimektedir. Ordu universitelerden farklılaştığı görülmektedir. Ordu göre ortalamaların yüksek olduğu belirlenmiştir.

Tablo 4. Not Ortalaması Değişkenine Göre Jonckheere-Terpstra Analizi Değerleri

\begin{tabular}{|c|c|c|c|c|c|c|c|}
\hline & $\begin{array}{c}\text { Not } \\
\text { ortalamas1 } \\
\text { seviyesi }\end{array}$ & $\mathrm{N}$ & $\begin{array}{l}\text { Gözlemlenen } \\
\text { J-T İstatistiği }\end{array}$ & $\begin{array}{l}\text { Ortalama } \\
\text { J-T } \\
\text { İstatistiği }\end{array}$ & $\begin{array}{c}\text { Std. } \\
\text { Sapma J-T } \\
\text { İstatistiği }\end{array}$ & $\begin{array}{l}\text { Std. J-T } \\
\text { İstatistiği }\end{array}$ & $\mathrm{p}$ \\
\hline $\begin{array}{l}\text { Antrenörün yeterli } \\
\text { bilgi birikimine ve } \\
\text { deneyimine sahip } \\
\text { olması performansı } \\
\text { etkiler }\end{array}$ & 5 & 395 & 27768,500 & 27204,000 & 1146,644 & ,492 & ,623 \\
\hline $\begin{array}{l}\text { Antrenman ve } \\
\text { müsabaka dönemleri } \\
\text { dışında antrenörle } \\
\text { sosyal ve kültürel } \\
\text { ilişki kurulmalıdır }\end{array}$ & 5 & 395 & 25260,500 & 27204,000 & 1153,951 & $-1,684$ & ,029 \\
\hline $\begin{array}{l}\text { Antrenör takımda } \\
\text { arkadaşlık } \\
\text { ilişkilerine çok özen } \\
\text { gösterir }\end{array}$ & 5 & 395 & 27688,500 & 27204,000 & 1148,399 & ,422 & ,673 \\
\hline $\begin{array}{l}\text { Antrenörün } \\
\text { takımdaki sporcuları } \\
\text { takdir etmesi } \\
\text { performansı etkiler }\end{array}$ & 5 & 394 & 28184,000 & 27082,000 & 1147,071 & ,961 & ,337 \\
\hline $\begin{array}{l}\text { Antrenörün } \\
\text { sporcuların özel } \\
\text { yaşantıları ile } \\
\text { ilgilenmesi takımın } \\
\text { performansını etkiler }\end{array}$ & 5 & 395 & 28413,000 & 27204,000 & 1165,505 & 1,037 & ,030 \\
\hline $\begin{array}{l}\text { Antrenörün sert ve } \\
\text { kırıcı konuşması } \\
\text { performansı } \\
\text { etkilemez }\end{array}$ & 5 & 395 & 27515,000 & 27204,000 & 1154,122 & ,269 &, 788 \\
\hline
\end{tabular}



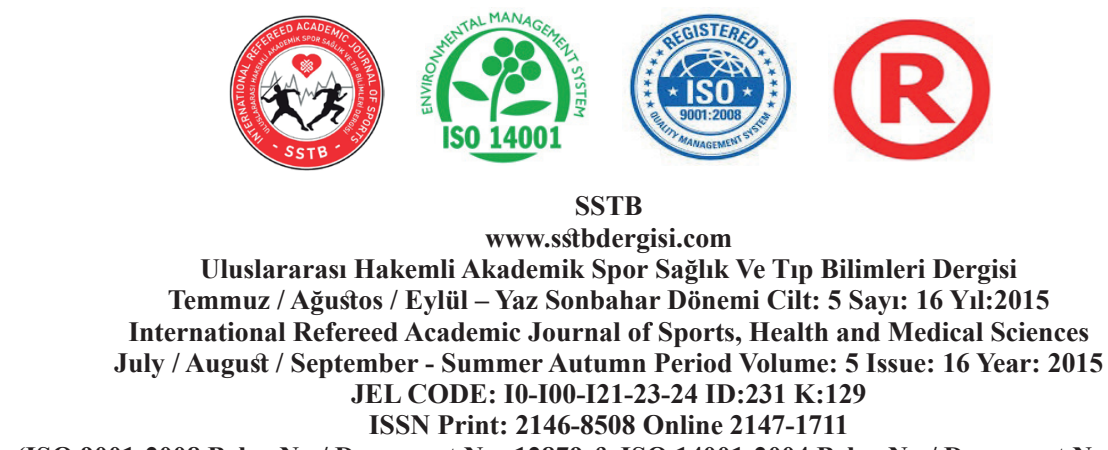

Temmuz / Ağustos / Eylül - Yaz Sonbahar Dönemi Cilt: 5 Sayı: 16 Yıl:2015
Tem

International Refereed Academic Journal of Sports, Health and Medical Sciences

JEL CODE: I0-I00-I21-23-24 ID:231 K:129

(ISO 9001-2008 Belge No / Document No: 12879 \& ISO 14001-2004 Belge No / Document No: 12880)

(MARKA PATENT NO: TRADEMARK)

(2015/04315- 2015-GE-18972)

\begin{tabular}{|c|c|c|c|c|c|c|c|}
\hline $\begin{array}{l}\text { Takım içinde } \\
\text { sporcular üzerine } \\
\text { düşen sorumlulukları } \\
\text { yerine getirirler }\end{array}$ & 5 & 395 & 27195,500 & 27204,000 & 1170,996 &,- 007 & ,994 \\
\hline $\begin{array}{l}\text { Yedek olunan } \\
\text { maçlarda bile } \\
\text { takımın başarısı } \\
\text { önemsenir }\end{array}$ & 5 & 395 & 29000,500 & 27204,000 & 1157,232 & 1,552 & ,012 \\
\hline $\begin{array}{l}\text { Takım arkadaşları } \\
\text { ile sorunları } \\
\text { konuşabilmek } \\
\text { performansı etkiler }\end{array}$ & 5 & 395 & 27215,000 & 27204,000 & 1174,339 & ,009 & ,993 \\
\hline $\begin{array}{l}\text { Takım başarısında } \\
\text { oynayanlar kadar } \\
\text { yedek oyuncularında } \\
\text { etkisi vardır }\end{array}$ & 5 & 395 & 28856,500 & 27204,000 & 1165,005 & 1,418 &, 156 \\
\hline $\begin{array}{l}\text { Takımla ilgili } \\
\text { önemli kararlar } \\
\text { alınmadan önce } \\
\text { tüm oyuncuların } \\
\text { fikirlerinin alınması } \\
\text { performans1 etkiler }\end{array}$ & 5 & 395 & 28529,000 & 27204,000 & 1162,156 & 1,140 &, 025 \\
\hline $\begin{array}{l}\text { Önemli maçlar } \\
\text { öncesinde takım } \\
\text { içindeki dayanışma } \\
\text { ve yardımlaşma } \\
\text { performansı etkiler }\end{array}$ & 5 & 395 & 27033,000 & 27204,000 & 1134,833 &,- 151 & ,880 \\
\hline $\begin{array}{l}\text { Aynı mevkii } \\
\text { paylaşan sporcuların } \\
\text { rekabeti performansı } \\
\text { etkiler }\end{array}$ & 5 & 395 & 26180,500 & 27204,000 & 1125,311 &,- 910 & ,363 \\
\hline $\begin{array}{l}\text { Başarısız olunan } \\
\text { maçlardan sonra } \\
\text { başarısızlığın } \\
\text { nedenlerinin } \\
\text { tartışılması } \\
\text { performansı etkiler }\end{array}$ & 5 & 395 & 27670,000 & 27204,000 & 1143,061 & ,408 & ,684 \\
\hline
\end{tabular}


www.sstbdergisi.com

Uluslararası Hakemli Akademik Spor Sağlık Ve Tıp Bilimleri Dergisi

Temmuz / Ağustos / Eylül - Yaz Sonbahar Dönemi Cilt: 5 Sayı: 16 Yıl:2015

International Refereed Academic Journal of Sports, Health and Medical Sciences

July / August / September - Summer Autumn Period Volume: 5 Issue: 16 Year: 2015

JEL CODE: I0-I00-I21-23-24 ID:231 K:129

ISSN Print: 2146-8508 Online 2147-1711

(ISO 9001-2008 Belge No / Document No: 12879 \& ISO 14001-2004 Belge No / Document No: 12880)

(MARKA PATENT NO: TRADEMARK)

(2015/04315- 2015-GE-18972)

\begin{tabular}{|c|c|c|c|c|c|c|c|}
\hline $\begin{array}{l}\text { Takım içinde } \\
\text { bazı oyuncular } \\
\text { ayrıcalıklıdır }\end{array}$ & 5 & 395 & 29566,000 & 27204,000 & 1169,737 & 2,019 &, 043 \\
\hline $\begin{array}{l}\text { Kulüpte takımın } \\
\text { performansını } \\
\text { olumlu yönde } \\
\text { etkileyecek bütün } \\
\text { olanaklar sağlanır }\end{array}$ & 5 & 395 & 27407,000 & 27204,000 & 1156,784 & ,175 & ,861 \\
\hline $\begin{array}{l}\text { Yöneticiler takım } \\
\text { içindeki arkadaşlığın } \\
\text { sağlanmasında } \\
\text { etkilidir }\end{array}$ & 5 & 395 & 28889,000 & 27204,000 & 1169,145 & 1,441 &, 015 \\
\hline $\begin{array}{l}\text { Yöneticiler başarısız } \\
\text { sonuçlarda bile } \\
\text { sporcuların kişilik } \\
\text { haklarına her zaman } \\
\text { saygı gösterir }\end{array}$ & 5 & 395 & 28261,500 & 27204,000 & 1177,733 & ,898 & ,369 \\
\hline $\begin{array}{l}\text { Yöneticilerin } \\
\text { sporcular } \\
\text { sakatlandığında } \\
\text { maddi ve manevi her } \\
\text { türlü desteği vermesi } \\
\text { performans1 etkiler }\end{array}$ & 5 & 395 & 28370,000 & 27204,000 & 1184,657 & ,984 &, 325 \\
\hline $\begin{array}{l}\text { Yöneticilere } \\
\text { ulaşmada ve } \\
\text { sorunların } \\
\text { anlatılmasında } \\
\text { genelde sıkıntı } \\
\text { çekilir }\end{array}$ & 5 & 395 & 29234,000 & 27204,000 & 1165,335 & 1,742 &, 028 \\
\hline
\end{tabular}

H0: Not ortalamasl, tercih nedenleri üzerinde farkllĭğa neden olan bir değişken değildir.

Jonckheere-Terpstra analizi ile not ortalamas1nın, tercih nedenleri üzerindeki etkisi belirlenmeye çalışılmıştır. Buna göre; Asymp sig (p) değeri 0,05 'in üstünde bulunan tercih nedeni not ortalamasına göre farklılaşmadığı, altında bulunan tercih nedeni ise not ortalamasına göre farklılaş̧ı̆ı̆ını göstermektedir. Not ortalamalarına göre farklılığa bakıldığında, 2.49'a kadar olan not ortalamalarının diğer not ortalamalarından farkllaş̧ı̆̆ı görülmektedir.

\section{TARTIŞMA VE SONUÇ}

Takım sporlarından iletişim gerek bireysel gerekse de takım performansına doğrudan etki eden 


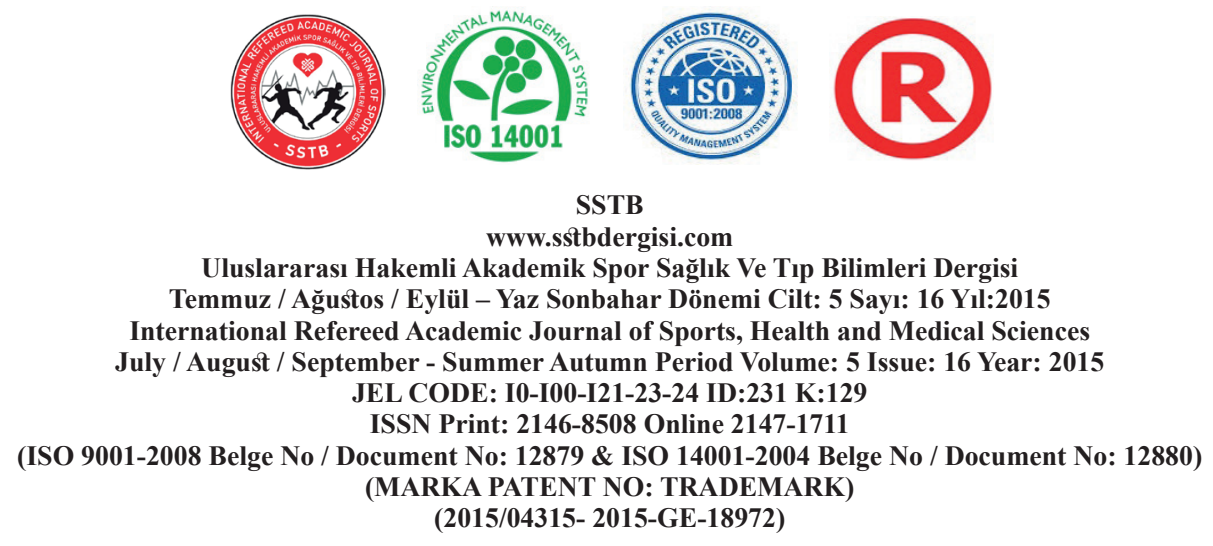

bir unsur olarak dikkat çekmektedir. Özellikle rekabetin üst düzeyde yaşandığı günümüzde performansın daha ileriye taşınması tek tek sporculardan oluşan takımın bir bütün halinde hareket edebilmesi ve bunun içinde birbirleri ile iletişim kanallarının sağlıkı işlemesi gerekmektedir. Aksi halde bireysel yeteneklerin takım performansına yansımaları yetersiz kalacak ve dolayısı ile başarısızlık kaçınılmaz olacaktır.

İletişimin performans verimi üzerindeki etkisinin bazı değişkenler açısından incelendiği çalışmada "Başarısız olunan maçlardan sonra başarısızlı̆ğın nedenlerinin tartşsılması performansı etkiler" $(, 026)$ ifadesi cinsiyet değişkeni açısından anlamlı bir farkl1lık göstermektedir.

Başarısız olunan maçlardan sonra başarısızlı̆ı̆n nedenlerinin tartşsılması performansı etkiler $(, 026)$ cinsiyete göre farklılaşmaktadır. Erkek öğrenci sporcuların ortalamalarının kız öğrenci sporculara göre daha yüksek olduğu anlaşılmaktadır.

Performansın öncül olduğu spor uğraşılarında başarı ve başarısızlık durumunda bunun nedenlerinin ortaya konularak daha iyiye ve ileriye gitmek için fikirlerin paylaşılması bireysel ve takım performansını doğrudan etkileyebilir diyebiliriz. Özellikle öz eleştiri kabiliyetinin takım içinde geliştirilmesi ile birlikte yapılan hatalara tekrar düşülmemesi ve herkesin kendisini daha yukarılara çekebilmesi açısından başarısız olunan maçlardan sonra takım içinde bir eleştiri

mekanizmasının oluşturulması sağlıklı sonuçlar ortaya çıkaracaktır.

Ancak araştırma sonuçlarına göre yukarıda ifade edilen tek bir faktör dışında cinsiyet değişkeni açısından başka anlamlı bir farkın olmadığı görülmektedir. Erkek ve bayan sporcuların iletişim ve performansa yönelik aynı bakış açılarına sahip oldukları söylenebilir. Grup üyeliğinden takımın bir parçası olma durumuna geçiş ya da aidiyet duygusu ve beraberinde başarının yakalanması iletişim özelinde sporcular açısından bir bütün olarak değerlendirilmiş̧ir diyebiliriz. Gerek erkek gerekse de bayan sporcuların elde edilen verilere göre anlamlı bir farklılık ortaya koymamaları başarılı bir takımın oluşturulmasında aynı görüşleri yansıtttğını söyleyebiliriz.

Mutlu vd. (2014) ve Çavuşoğlu ve Günay (2014) tarafindan yapılan araştırmalarda sporcu öğrencilerin iletişim düzeyi ortalamalarının cinsiyet değişkenine göre istatistiksel olarak anlamlı bir fark teşkil etmediği ortaya konulmuştur. Yine Dalkılıç (2011) tarafindan yapılan bir araştırmada cinsiyet değişkeni açısından spor yapan erkek ve bayanların iletişim becerilerinde anlamlı bir farkın olmadığı anlaşılmaktadır.

Diğer yandan Abakay ve Kuru (2013) tarafindan yapılan bir çalışmada futbolda antrenör-sporcu iletişiminin yüksek olmasının kadın futbolcuların başarı motivasyon düzeylerini pozitif yönde etkilediği anlaşılmaktadır. Ayrıca Yıldırım ve Abakay (2015) yapmış oldukları araştırmada, 


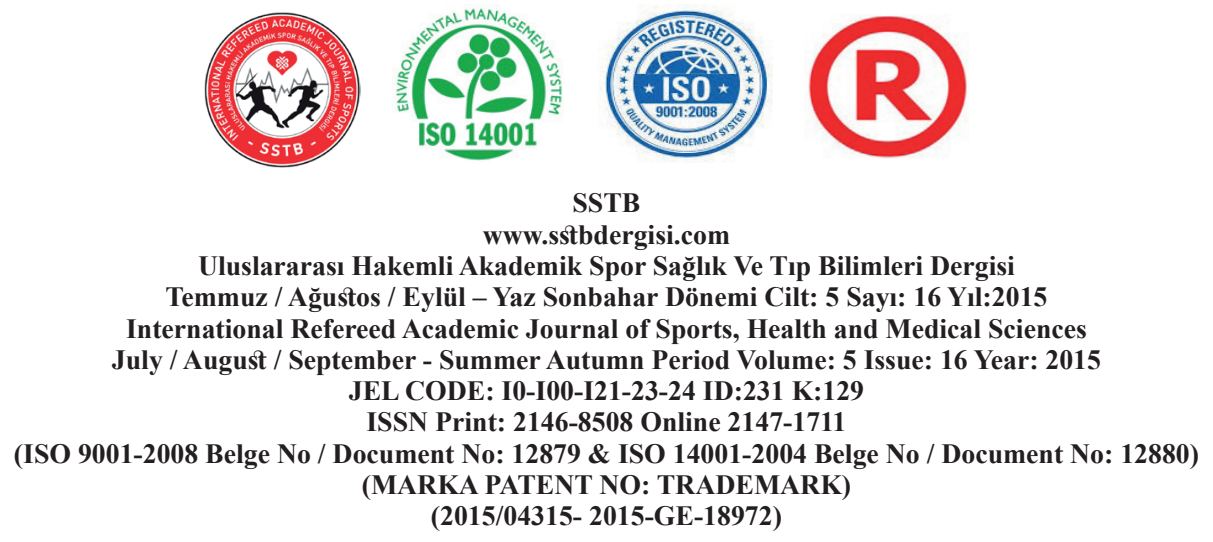

kadın ve erkek hokeycilerin iletişim beceri düzeylerinin genel olarak yüksek olduğu yönünde bir sonuca varmıştır.

Kruskal Wallis analizi ile okulun, iletişimin performans verimi üzerindeki etkisi belirlenmeye çalışılmıştır. Buna göre; Ordu ve Rize Üniversitelerinin diğer üniversitelerden farklılaştığı ve bu iki üniversitenin diğer üniversitelere göre ortalamalarının yüksek olduğu belirlenmiştir. Analiz sonuçlarına bakıldığında, üniversite değişkenine göre farklılığa neden olan faktörler aşağıdaki gibi sunulmuştur.

$\checkmark$ Antrenörün yeterli bilgi birikimine ve deneyimine sahip olması performansı etkiler.

$\checkmark$ Antrenman ve müsabaka dönemleri dışında antrenörle sosyal ve kültürel ilişki kurulmalıdır

$\checkmark$ Antrenör takımda arkadaşlık ilişkilerine çok özen gösterir

$\checkmark$ Antrenörün takımdaki sporcuları takdir etmesi performansı etkiler

$\checkmark$ Antrenörün sporcuların özel yaşantıları ile ilgilenmesi takımın performansını etkiler

$\checkmark$ Antrenörün sert ve kırıcı konuşması performansı etkilemez

Takım içinde sporcular üzerine düşen sorumlulukları yerine getirirler

$\checkmark$ Yedek olunan maçlarda bile takımın başarısı önemsenir $\checkmark$ Önemli maçlar öncesinde takım içindeki dayanışma ve yardımlaşma performansı etkiler

$\checkmark$ Aynı mevkii paylaşan sporcuların rekabeti performansı etkiler

$\checkmark$ Yöneticiler takım içindeki arkadaşlığın sağlanmasında etkilidir

$\checkmark$ Yöneticilere ulaşmada ve sorunların anlatılmasında genelde sıkıntı çekilir

Antrenör, yönetici ve sporcu arasındaki ilişki ve iletişim süreci takım sporlarında oldukça önemlidir. Zira kalabalık sporcu grubu ve antrenör ekibi arasındaki bilgi paylaşımı ve bu süreçte idarecilerin sergiledikleri tutumlar başarı ya da başarısızlığ etkileyebilmektedir. Dolayısı ile takım içinde tüm tarafların bilgi paylaşımına açık olmaları ve duyarlı davranmaları sağlıklı bir iletişime bağlıdır ki; bu durum performansa yansiyan davranışsal bir eylemdir. Bir takımın sadece sporculardan oluşmadığı, antrenör ve yöneticilerin de bu süreçte doğrudan etkili olduklarını söylemek yanlış olmayacaktır. Dolayısı ile başarının yakalanmasında bütünsel bir yapının teşkil edilmesi ve tüm takım üyeleri arasında verimli ve nitelikli bir iletişim ağının tesis edilmesinden söz etmek yanlış olmayacaktır. Bu süreç takımda aidiyet duygusunu güçlendirecek ve beraberinde sorumlulukların paylaşılması ile birlikte görev anlayışı sağlıklı bir şekilde işleyecek ve nihayetinde takımın başarıyı elde etmesi gibi olumlu bir sonuç ortaya çıkacaktır. 


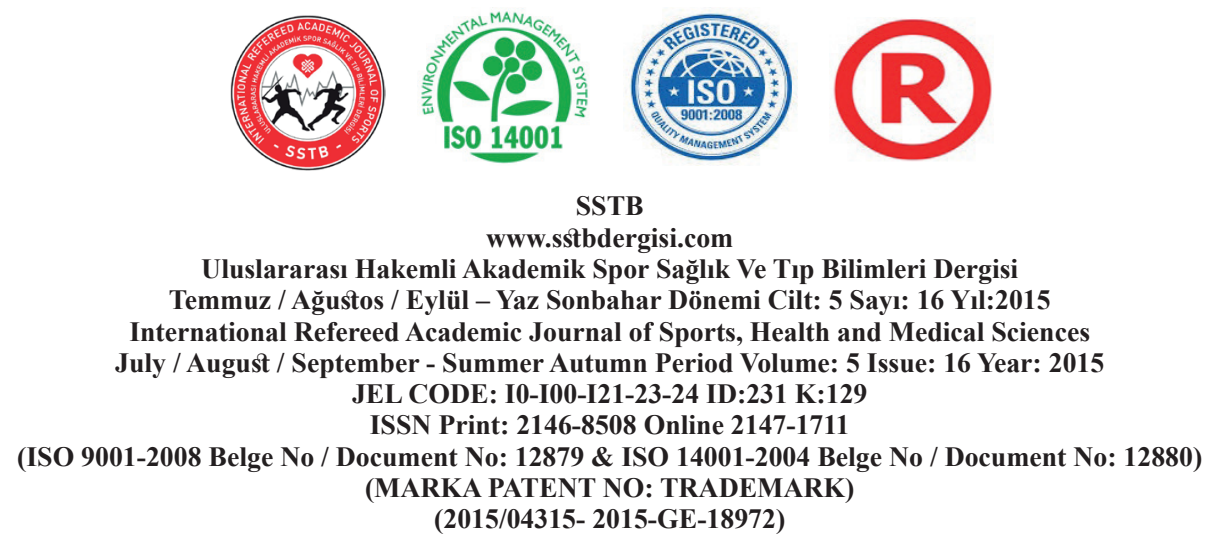

Takım içi iletişimle ilgili olarak Erdoğan vd. (2014), takım içinde iletişim olduğu sürece performansin olumlu yönde etkileneceğini ifade ederken; Ulukan (2012) ise antrenör ve kulüp yöneticilerinin, bünyesinde bulunduğu sporcuların iletişim becerilerini yüksek seviyede tutmaları durumunda sporcuların performanslarını olumlu yönde etkileneceğine dikkat çekmektedir.

İletişim, takım sporlarında başarılı bir performansa aracılık eden takım bütünlüğü ve takım yapısının güçlendirilmesi noktasında nicel ve nitel bir misyona sahiptir diyebiliriz. Zira birçok farklı karaktere sahip bireylerden oluşan bir grubun takım olabilmesi sağlıklı bir iletişim ile mümkündür. Her bir bireyin ortak bir amaç etrafinda toplanabilmesi ve bireysel performansını takım sporuna yansitabilmesi de yine bu bireyler arasında oluşturulacak bağ ile gerçekleşebilir.

Takım bütünlüğü, yapısı ve takım içi iletişim sporcuların memnuniyetlerinde oldukça etkilidir (Onağ ve Tepeci 2014). Tek tek bireylerin ve takım halinde sporcuların memnuniyet düzeylerinin artması takım performansının yukarılara çekilmesi anlamına gelebilir. Bununla beraber takım bütünlügünün tesisi ile birlikte sporcuların başarı için ortak bir paydada buluşması, başarı gibi ortak bir amaç etrafinda toplanan farklı bireylerin takım olması anlamına gelmektedir.

$\mathrm{Bu}$ iletişim süreci ve performansın artırılmasının kendiliğinden oluşacak bir durum olmadığ1 da bir gerçektir. Gerek antrenörlerin gerekse de sporcuların ve hatta yöneticilerin bu süreci yakından takip etmeleri ve bilgi paylaşımına açık olmaları gerekmektedir. Dobrescu (2014), sporcular ve antrenörlerin mümkün olduğunca iletişim yöntemlerini antrenmanların amaçlarına göre bilmeleri ve uygulamaları gerektiğinin altını çizmektedir.

Hem bireysel sporlarda hem de takım sporlarında antrenör ve sporcu arasındaki iletişim başarılı bir performansın sergilenmesine öncülük etmektedir. Sporcular ile doğrudan kurulabilecek temaslar ve sözlü ve sözsüz iletişim kanalları sporcuların takım olmalarına aracılık edebilmekte; bireysel sporlarda ise maksimum verimin sağlanmasında işlevsel bir köprü olabilmektedir.

Y1lmaz vd. (2009), bireysel ve takım sporları antrenörlerine ilişkin yapmış oldukları araştırmada bireysel spor antrenörlerinin iletişim becerileri$\operatorname{nin}(X=4,36)$, takım sporları antrenörlerine göre $(X=4,15)$ daha yüksek olduğunu ortaya koymuştur. Burada bireysel sporlarda antrenör ve sporcuların daha yoğun bir iletişim halinde olduğunu söylemek yanlış olmayacaktır. Zira takım sporlarına göre daha spesifik ve kişisel temasın rahatlıkla sağlanabilmesi bu sonuca zemin hazırlamıştır diyebiliriz. Ancak bu sonucun takım sporları antrenörleri üzerinde genellenmesinin sakıncalı olabileceği de göz önünde bulundurulmalıdır.

Antrenör, sporcu ve yönetici üçgeni içerisinde iletişimin önemine ilişkin hentbol antrenörlerinin iletişim becerilerini değerlendiren Kabadayı (2010), 


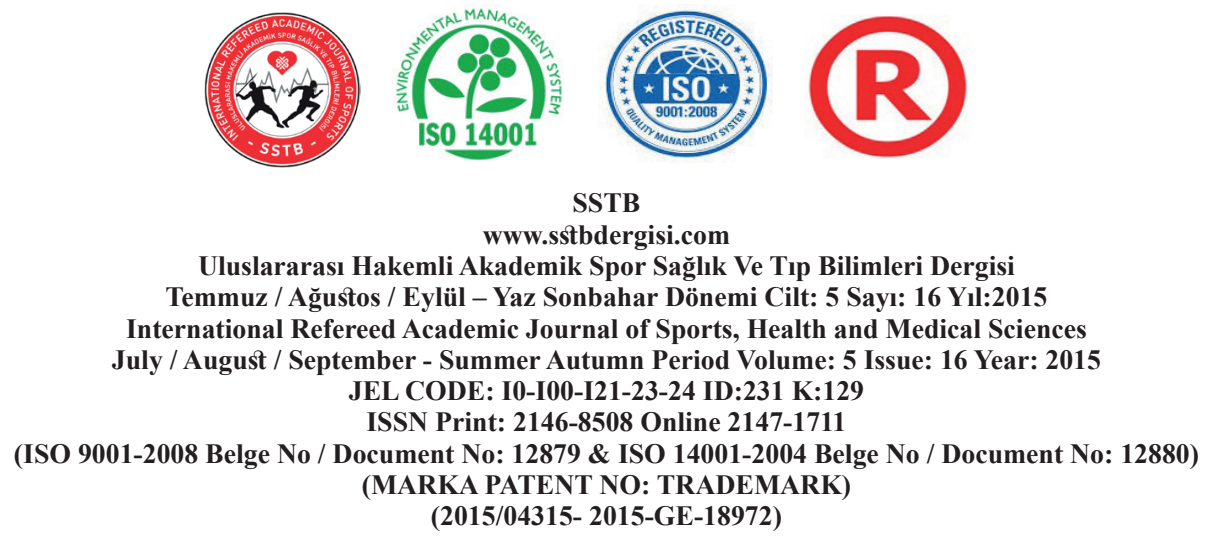

antrenörlerin iletişim becerileri değerlendirmelerinin sporculara göre vasat, antrenör ve yöneticilere göre ise etkili fakat geliştirilmesi gereken düzeyde olduklarını saptamıştır. Elde edilen sonuçlara göre ise antrenörlerin sporcularını dinleme ve sorunları ile ilgilenme konusunda daha duyarlı davranmaları gerektiği sonucu ortaya çıkmıştır (Kabaday1, 2010).

Yukarıda da ifade edildiği üzere sağlıklı bir iletişimin oluşturulması ve bunun performansa yansıması için tüm takım üyelerinin bilgi paylaşımına açık olmaları ve daha duyarlı davranmaları gerekmektedir. Özellikle antrenörlerin sporcuları dinleme noktasında algılarının çok yüksek olması elzemdir. Zira sporculara antrenörün yaklaşımı ve sorunlara çözüm getirebilme becerisi sporcu ve antrenör arasındaki güçlü bir iletişim kanalının tesisi ile mümkün görünmektedir.

Jonckheere-Terpstra analizi ile not ortalamasının, iletişimin performans verimi üzerindeki etkisi belirlenmeye çalışılmıştır. Buna göre; Asymp sig değeri 0,05 'in üstünde bulunan tercih nedeni not ortalamasına göre farklılaşmadığı, altında bulunan tercih nedeni ise not ortalamasina göre farklılaştığını göstermektedir.

Not ortalamalarına göre farklılığa bakıldığında, 2.49'a kadar olan not ortalamalarının diğer not ortalamalarından farklılaştığı görülmektedir. 2.49 not ortalamasının eşik değer olduğu, aşağıdaki maddelerde 2.49'un üzerinde farklılaştığı diğerlerinin ise altında kaldığı belirlenmiştir. Yapılan analiz sonuçlarına göre not ortalaması bakımından farklılığa neden olan maddeler aşağıda verilmiştir.

$\checkmark$ Antrenman ve müsabaka dönemleri dışında antrenör ile sosyal ve kültürel ilişki kurulmalıdır

$\checkmark$ Antrenörün sporcuların özel yaşantıları ile ilgilenmesi takımın performansını etkiler

$\checkmark$ Yedek olunan maçlarda bile takımın başarısı önemsenir

$\checkmark$ Takımla ilgili önemli kararlar alınmadan önce tüm oyuncuların fikirlerinin alınması performansı etkiler

$\checkmark$ Takım içinde bazı oyuncular ayrıcalıklıdır

$\checkmark$ Yöneticiler takım içindeki arkadaşlığın sağlanmasında etkilidir

$\checkmark$ Yöneticilere ulaşmada ve sorunların anlatılmasında genelde sıkıntı çekilir

Özşaker (2013), spor yapma ve fiziksel aktivitede bulunmanın özellikle üniversite öğrencilerine etkili bir sosyalleşme ortamı sağlayarak iletişim becerilerinin gelişmesini katkı sağladığını ifade ederken; yapmış olduğu araştırmada spor yapan öğrencilerin iletişim becerileri ve benlik saygı skorlarının spor yapmayan öğrencilere göre yüksek olduğunu ortaya koymaktadır.

Üniversite öğrencilerinin spor ve fiziksel aktiviteye katılım düzeyi ve sıklığı onların daha fazla sosyalleşme firsatı yakalamalarına imkan sağlamaktadır. Bu süreçte öğrencilerin iletişim 


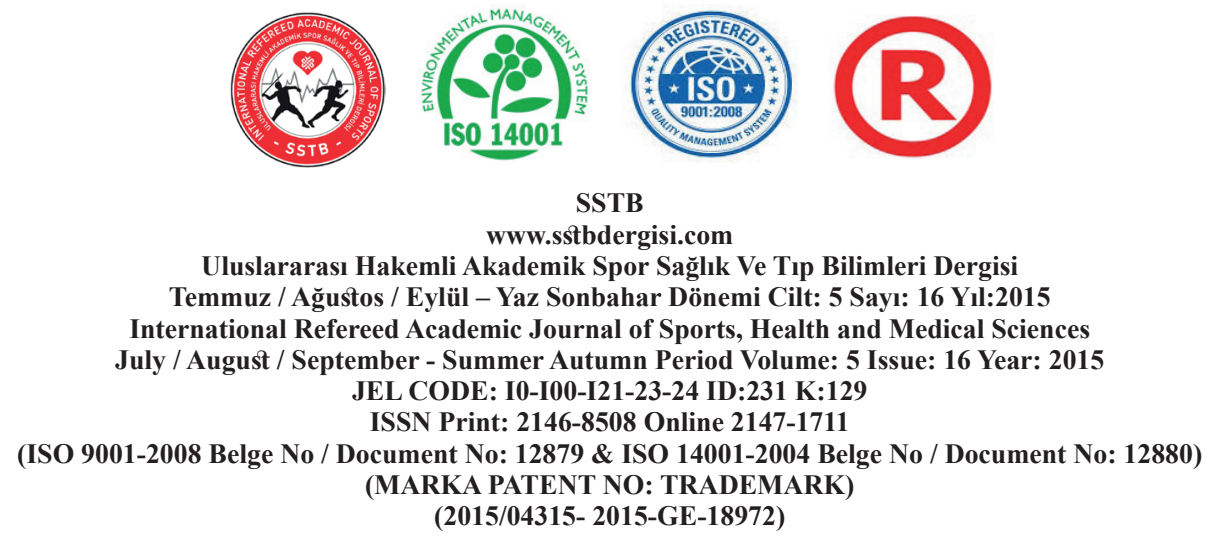

beceri ve düzeyleri gelişmekte ve bir birey olarak yaşamın her evresine adaptasyonları kolaylaşmaktadır. Bu bağlamda spor ve iletişim becerisi arasındaki korelasyonun pozitif yönde olması beklenmektedir.

Tepeköylü vd. (2009) tarafindan yapılan araştırmada Beden Eğitimi ve Spor Yüksekokulu öğrencilerinin iletişim beceri algılarına yönelik puan ortalamaları yüksek bulunurken; yine Tepeköylü vd. (2011) tarafindan yapılan bir araştırmada da üniversite takımlarındaki sporcu-öğrencilerin iletişim beceri düzeylerinin spor yapmayan öğrencilerden daha yükse olduğu saptanmıştır.

Takım olma ve performans olarak başarıyı yakalamaya ilişkin olarak da Şahin (2012) tarafından yapılan bir çalışmada, başarılı grupta yer alan voleybol oyuncularının iletişim beceri puanlarının yüksek olduğu (95.44) belirlenmiştir.

Üniversite ve spor yapma alışkanlığı arasındaki ilişkiyi iletişim becerisi özelinde değerlendiren Kılcigil vd, (2009) Ankara Üniversitesi Beden Eğitimi ve Spor Yüksekokulu Spor Yöneticiliği öğrencilerinin iletişim beceri puanlarının öğretmenlik ve antrenörlük bölümü öğrencilerine göre daha düşük olduğunu belirlemekle birlikte; Çukurova Üniversitesi Beden Eğitimi ve Spor Yüksekokulu öğretmenlik bölümü öğrencilerinin iletişim beceri puanlarının Ankara Üniversitesi Beden Eğitimi ve Spor Yüksekokulu öğretmenlik bölümü öğrencilerinden daha yüksek olduğunu ortaya koymuştur (Kılcıgil vd., 2009).
Gerek akademik anlamda gerekse de sportif anlamda üniversite öğrencilerinin başarılı olabilmelerini etkiyen bir çok unsurdan birisi de iletişimdir. Sağlıklı bir iletişim becerisi öğrenci-sporcu metaforunu daha ileriye taşıyacak ve nitelikli bireylerin ve sporcuların yetişmesine aracılık edecektir. Özellikle üniversite takımlarında yer alan öğrencilerin takımlarında başarılı olabilmeleri zaman zaman hiç tanımadığı diğer öğrenciler ile birlikte hareket etmesine neden olacaktır. Böyle bir durumda hem insani yönden hem de sporculuk açısından duyarlı ve iletişime açık bireyler olmaları gerekmektedir diyebiliriz.

Takım sporlarında performansı etkileyen birçok unsur vardır. Teknik, taktik ve sportif beceri bunların başında gelmektedir. Bunların dışında belki de en önemli unsurların başında takım içi iletişim yer almaktadır. Birçok farklı özelliğe sahip insanın bir araya gelmesi ve ortak amaçlar için hareket edebilmesi takım içi iletişim ile mümkün olabilmektedir. Takım başarısı ve üst düzey performansın sergilenmesi antrenör, sporcu ve yönetici arasındaki etkili ve sağlıklı iletişim inşa edilmesi mümkündür diyebiliriz. Özellikle üniversite çağındaki gençlerin karşısındakini dinlemesi ve anlaması ve bu anlamda ortak hareket edebilmesi toplumsal dinamikler açısından da önemlidir.

Kitlelerin spora yönelerek bireysel ve takım halinde başarıyı arzulaması bir çok farklı değişkenin bir araya gelmesi ile gerçekleşebilir. Yukarıda da ifade edildiği üzere bu değişkenlerden birisi de 


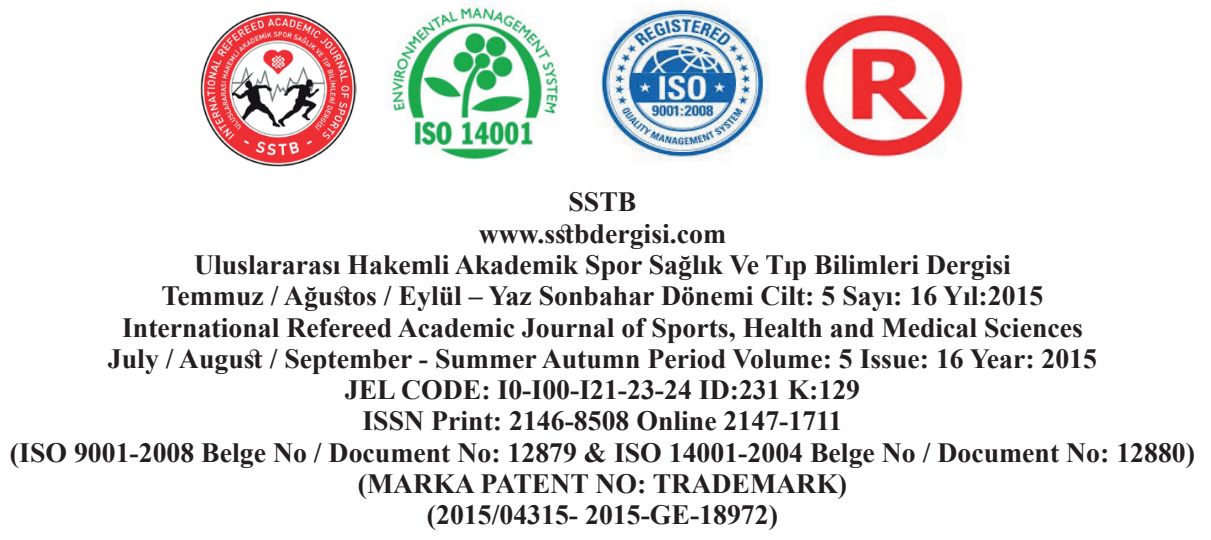

iletişim becerisidir. Bu becerinin geliştirilmesi ve takım içinde uygulamaya aktarılması takım performansını yukarıya çekecek ve bireysel memnuniyetin başarıya yansımasını sağlayacaktır.

Netice itibari ile başta antrenörlerin iletişim hususunda daha hassas ve duyarlı olmaları ve bu alanda kendilerini geliştirmeye açık olmaları gerekmektedir. Rol model olmaları ve takımlarının başarılarında birincil derecede etkili oldukları için antrenörlerin iletişim konusunda gerektiğinde akademik destek almaları dahi söz konusu olabilir. Öğrenci sporcular açısından değerlendirildiğinde ise bireylerin bir grup olabilmeleri ve akabinde bu grubun takım olabilmesi için iletişim kanallarının açık olması elzemdir. Bireysel olarak yeteneklerinin farkında olan öğrencilerin takımın bir parçası olarak daha başarılı olabileceğinin bilincine varması ile birlikte etrafindaki diğer takım üyeleri ile uyum ve düzen içinde hareket etmeleri başarıyı ortaya çıkaracaktır.

\section{KAYNAKLAR}

$A B A K A Y, U$., KURU, E., (2013). Kadın Futbolcularda Antrenörü İletişim Düzeyi ve Başarı Motivasyonu İlişkisi. Gaziantep Üniversitesi Sosyal Bilimler Dergisi, 12(2): 20-33

ÇAMDERELİ, M., (2008). İletişime Giriş. 1. Baskı. İstanbul: Dem Yayınları.

ÇAVUŞOĞLU, S.B., GÜNAY, G., (2014). İstanbul Üniversitesi Beden Eğitimi ve Spor Yüksekokulu Öğrencilerinin İletişim Bece- rileri Algı Düzeylerinin Farklı Değişkenler Açısından Değerlendirilmesi. Organizasyon ve Yönetim Bilimleri Dergisi, 6(1): 107-121

DALKILIÇ, M., (2011). İlköğretim Öğrencilerinin Sportif Faaliyetlere Katılım Düzeyi ve İletişim Becerileri Düzeyi Arasındaki İlişkilerin İncelenmesi. Karamanoğlu Mehmet Bey Üniversitesi. Sosyal Bilimler Enstitüsü, Yüksek Lisans Tezi, Karaman

DOBRESCU, T., (2014). The Rloe of Non-Verbal Communication in The Coach-Athlete Relationship. Social and Behavioral Science, 149: 286-291

ERDOĞAN, N., ZEKIOĞLU, A., DORAK, F., (2014). Hentbol Antrenörlerine Göre Sporcuların Performansını Psikolojik Yönden Etkileyen Faktörler Nelerdir? Nitel Çalışma. International Journal of Science, Culture and Sport, Özel Sayı 1: 194-207

GIRGIN, A., (2002). Uluslararası İletişim. 1. Baskı. İstanbul: Der Yayınları

GÜNGÖR, N., (2011). İletişim Kuramlar-Yaklaşımlar. 1. Baskı. Ankara: Siyasal Kitabevi HERGÜNER, G., GÜVEN, Ö., YAMAN, M., (1997). Sporun üniversite öğrencilerinin iletişim beceri düzeylerine etkisi. Pamukkale Üniversitesi Eğitim Fakültesi Dergisi, 3: $95-101$ 


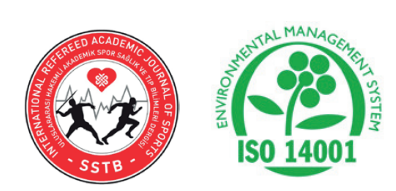

SSTB

www.sstbdergisi.com

Uluslararası Hakemli Akademik Spor Sağlık Ve Tıp Bilimleri Dergisi

Temmuz / Ağustos / Eylül - Yaz Sonbahar Dönemi Cilt: 5 Sayı: 16 Yıl:2015

International Refereed Academic Journal of Sports, Health and Medical Sciences

July / August / September - Summer Autumn Period Volume: 5 Issue: 16 Year: 2015

JEL CODE: I0-I00-I21-23-24 ID:231 K:129

ISSN Print: 2146-8508 Online 2147-1711

(ISO 9001-2008 Belge No / Document No: 12879 \& ISO 14001-2004 Belge No / Document No: 12880)

(MARKA PATENT NO: TRADEMARK)

(2015/04315- 2015-GE-18972)

KABADAYI, S., (2010). Hentbol Antrenörlerinin İletişim Becerilerinin Değerlendirilmesi (Hentbol Süper Lig Örneği). Anadolu Üniversitesi. Sosyal Bilimler Enstitüsü. Doktora Tezi. Eskişehir

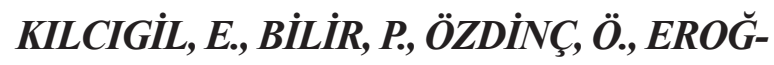
LU, K., EROĞLU, B., (2009). İki Farkl1 Üniversitenin Beden Eğitimi ve Spor Yüksekokulu Öğrencilerinin İletişim Becerilerinin Değerlendirilmesi. Spormetre, 7(1): 19-28

MUTLU, T.O., ŞENTÜRK, H.E., ZORBA, E., (2014). Üniversite Öğrencisi Tenisçilerde Empatik Eğilim ve İletişim Becerisi. International Journal of Science, Culture and Sport, 1: 129-137

ONA $\breve{G}, Z$. TEPECI, M., (2014). Team Effectiveness in Sport Teams: The Effects of Team Cohesion, Intra Team Communicaiton and team Norms on Team member Satisfaction and Intent to Remain. Social and Behavioral Science, 150: 420-428

OSKAY, Ü., (2011). İletişimin ABC'si. 6. Bask1. İstanbul: Der Yayınları

ÖZKAN, M., (2010). İnsan İletişin ve Dil. 4. Baskı. İstanbul: Akademik Kitaplar

ÖZŞAKER, M., (2013). Beden Eğitimi ve Spor Yüksekokulu Öğrencilerinin İletişim Becerileri ve Benlik Saygılarının Değerlendirilmesi. International Journal of new Trends In Arts, Sports and Science Education, 2(3): 29-39
ŞAHIN, N., (2012). Elit Düzeyde Takım Sporu ve Bireysel Spor Yapan İki Grubun İletişim Becerilerinin Karşılaştırılması. Spormetre, 10(1): $13-16$

TEPEKÖYL ̈̈, Ö., SOYTÜRK, M., ÇAMLIYER, H., (2009). Beden Eğitimi ve Spor Yüksekokulu Öğrencilerinin İletişim Becerisi Algılarının Bazı değişkenler Açısından İncelenmesi. Spormetre, 7(3): 115-124

TEPEKÖYLÜ, Ö., SOYTÜRK, M., DAŞDAN, ADA, E.N., ÇAMLIYER, H., (2011). Üniversite Takımlarından Sporcu Olan Öğrenciler İle Spor Yapmayan Öğrencilerin İletişim beceri Düzeylerinin Karşılaştırılması. Spor Bilimleri Dergisi, 22(2): 45-53

ULUKAN, H., (2012). İletişim Becerilerinin Takım ve Bireysel Sporculara Olan Etkisi. Karamanoğlu Mehmet Bey Üniversitesi. Sosyal Bilimler Enstitüsü, Yüksek Lisans Tezi, Karaman

YETIM, A., CENGIZ, R., (2010). İletişim ve Spor. 1. Baskı. Ankara: Berikan Yayınevi

YILDIRIM, A., ABAKAY, U., (2015). Hokeycilerin iletişim becerileri ve saldırganlık düzeyleri arasındaki ilişkinin incelenmesi. İnönü Üniversitesi Beden Eğitimi ve Spor Bilimleri Dergisi, 2(1): 17-28

YILDIZ, Ö., (2004). Takım Sporlarından İletişimin Performans Verimine Etkisinin Araştırılması. 

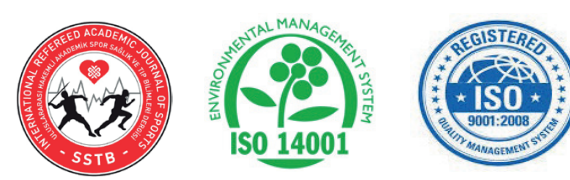

SSTB

www.sstbdergisi.com

Uluslararası Hakemli Akademik Spor Sağlık Ve Tıp Bilimleri Dergisi

Temmuz / Ağustos / Eylül - Yaz Sonbahar Dönemi Cilt: 5 Sayı: 16 Yıl:2015

International Refereed Academic Journal of Sports, Health and Medical Sciences

July / August / September - Summer Autumn Period Volume: 5 Issue: 16 Year: 2015

JEL CODE: I0-I00-I21-23-24 ID:231 K:129

ISSN Print: 2146-8508 Online 2147-1711

(ISO 9001-2008 Belge No / Document No: 12879 \& ISO 14001-2004 Belge No / Document No: 12880)

(MARKA PATENT NO: TRADEMARK)

(2015/04315- 2015-GE-18972)

Gazi Üniversitesi. Eğitim Bilimleri Enstitüsü.

Yüksek Lisans Tezi. Ankara

YILMAZ, I., ÇIMEN, Z., BEKTA, F., (2009).

Sporcu Algılamalarına Göre Bireysel ve Ta-

kım Sporları Antrenörlerinin İletişim Beceri

Düzeylerinin Karşılaştırılması. ATABESBD,

11(4): $52-57$ 


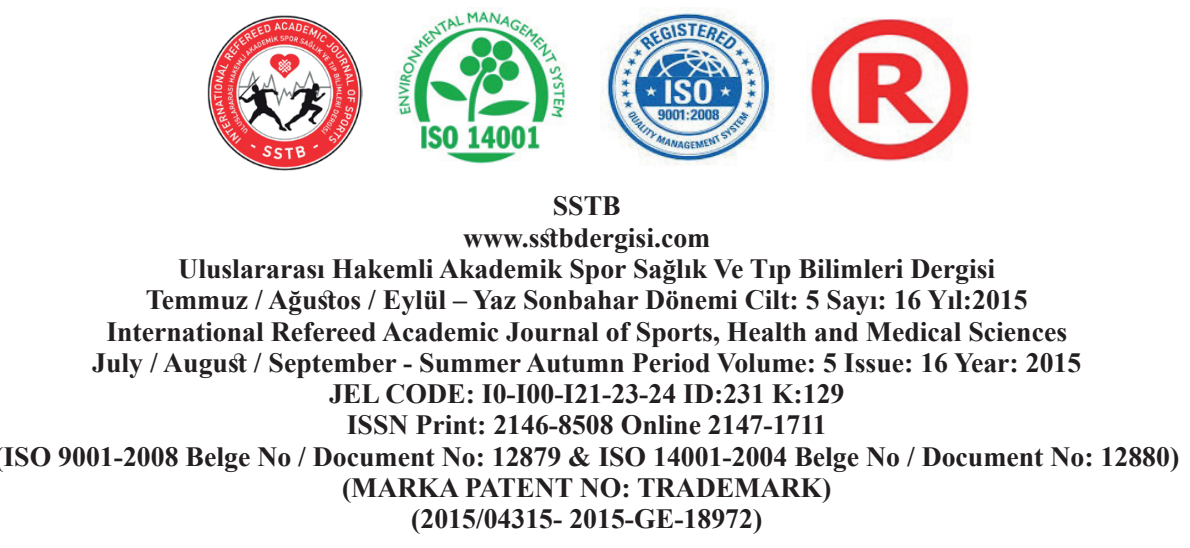

\section{EXTENDED SUMMARY}

Meaning and Importance: Communication is one of many factors that affect the success capacity of university students in sportive activities. Communication plays an important role, especially in team sports, for a group of player having different characters, natures and skills in achieving harmony and reflecting their personal performance on team performance. Therefore, it can be said that communication within the team is required for a group of individuals with certain skills to gain a team spirit. Purpose: This study aims to analyze the opinions of student-volleyball players, who join the Interuniversity Volleyball Minor League that was held in Antalya between 16-27 December 2014, regarding the impact of communication on performance capacity by different variables. Scope: Target population of the study are consists of student-volleyball players who study at a university in Turkey and play for volleyball teams of universities in the meantime whereas the sample group consists of student-volleyball players from 23 different universities who join the Interuniversity Volleyball Minor League that was held in Antalya between 16-27 December 2014. Challenges: Annual interuniversity tournaments organized by University Sports Federation of Turkey are held in different cities and universities of Turkey. Given this fact, it can be said that the study has been confined to a limited sample group. Because volleyball tournaments held at different places and periods have been failed to be addressed and the study has been confined to Volleyball Minor League Antalya Team, university teams in Antalya where the majority of participants come from constitute the scope of the study, which represents the major challenge. Method: A survey has been conducted on the participants to analyze the opinions of student-volleyball players regarding the impact of communication on performance capacity. The survey form applied is identical to the form applied by Y1ldiz (2004) in his postgraduate thesis entitled "The Impact of Communication on Performance Capacity in Team Sports". Data obtained from this survey has been analyzed by SPSS 21 statistical program. The Cronbach's Alpha coefficient of the applied survey has been calculated as 0.925 . The survey has been extended applying Man Whitney U, Kruskal Wallis, Jonckheere-Terpstra and Chi-Square techniques. Findings: The opinion of student-volleyball players regarding the impact of communication on performance capacity have been analyzed by certain variables. As for the gender variable, data analysis has revealed only one factor where gender causes difference. The notion "Discussing 

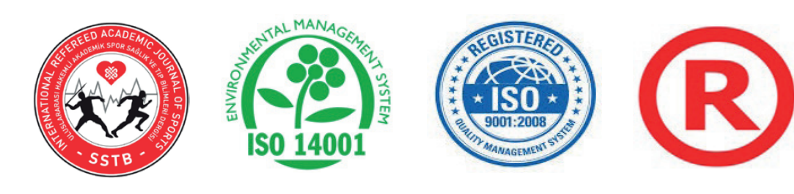

SSTB

www.sstbdergisi.com

Uluslararası Hakemli Akademik Spor Sağlık Ve Tıp Bilimleri Dergisi

Temmuz / Ağustos / Eylül - Yaz Sonbahar Dönemi Cilt: 5 Sayı: 16 Yıl:2015

International Refereed Academic Journal of Sports, Health and Medical Sciences

July / August / September - Summer Autumn Period Volume: 5 Issue: 16 Year: 2015

JEL CODE: I0-I00-I21-23-24 ID:231 K:129

ISSN Print: 2146-8508 Online 2147-1711

(ISO 9001-2008 Belge No / Document No: 12879 \& ISO 14001-2004 Belge No / Document No: 12880)

(MARKA PATENT NO: TRADEMARK)

(2015/04315- 2015-GE-18972)

the reasons of failure after a lost match affects performance negatively" is a difference by gender. As for the impact of communication on performance capacity by university variable, it has been found that the universities in Ordu and Rize are different than other universities, and the averages of both universities are higher than those of others. As for the impact of communication on performance capacity by the grade point average, a difference has been observed by grade point averages. The factors that cause difference by these variables according to the analysis applied have been elaborated under the section of findings. Result: As a result, meaningful differences have been detected between the opinions of students, who play in university volleyball teams, regarding the impact of communication on performance capacity by gender, university, grade point average variables. 